ARTICLE

Check for updates

\title{
Populism and competitive authoritarianism in Turkey
}

\section{Antonino Castaldo}

Instituto de Ciências Sociais, Universidade de Lisboa, Lisboa, Portugal

\begin{abstract}
The main goal of this paper is to explain the rise of competitive authoritarianism in Erdoğan's Turkey. The recent literature has mainly focused on the taxonomical debate about the type of regime established by Erdoğan, dealing only rarely with the factors explaining the Turkish autocratization. Building on Levitsky and Loxton's framework, which underlines the catalyst role played by the election of populist leaders for the rise of competitive authoritarianism in Latin America, the analysis identifies the interactions among Erdoğan's populism and threats and opportunities provided by both domestic and international environments as the major cause explaining Turkish autocratization.
\end{abstract}

\section{KEYWORDS}

Autocratization; populism; competitive authoritarianism; Turkey; Erdoğan; democratic backsliding

\section{Introduction}

The aim of this paper is to investigate the Turkish autocratization under the Justice and Development Party (Adalet ve Kalkınma Partisi-AKP) governments. According to the V-DEM Electoral Democracy Index, Turkey has been a stable low-quality electoral democracy during the 2000s, worsening its score since 2005 and falling below the democratic threshold in 2014 (Figure 1). The recent literature has engaged in a fervent debate about the type of regime established by Recep Tayyip Erdoğan, dealing only rarely with the factors explaining this regime change (Esen and Gümüşçü 2016; Konak and Özgür Dönmez 2015; Taş 2015). Hence, what kind of authoritarian shift or democratic reversal is Turkey experiencing? Which factors may explain the Turkish autocratization? I deal with the first question sharing Esen and Gümüşçü' findings (2016), according to which Turkey transitioned from a tutelary democracy to competitive authoritarianism (CA) since 2010. The second research question, which represents the core of this study, will be addressed applying to Turkey Levitsky and Loxton (2013) framework on the catalyst role played by populism for the rise of CA in Latin America. Hence, I claim that to explain the Turkish descent into competitive authoritarianism we have to focus on Erdoğan's populism and, above all, its interactions with the domestic and international environments in which he operated.

According to Levitsky and Loxton (2013), the literature addresses the negative impact of populism on democracy, but the causal mechanisms linking this phenomenon to autocratization remain poorly understood. Selecting the Turkish case, I will

CONTACT Antonino Castaldo Antonino.castaldo@gmail.com @ Instituto de Ciências Sociais, Universidade de Lisboa, Av. Professor Aníbal de Bettencourt 9, Lisboa, 1600-189, Portugal 


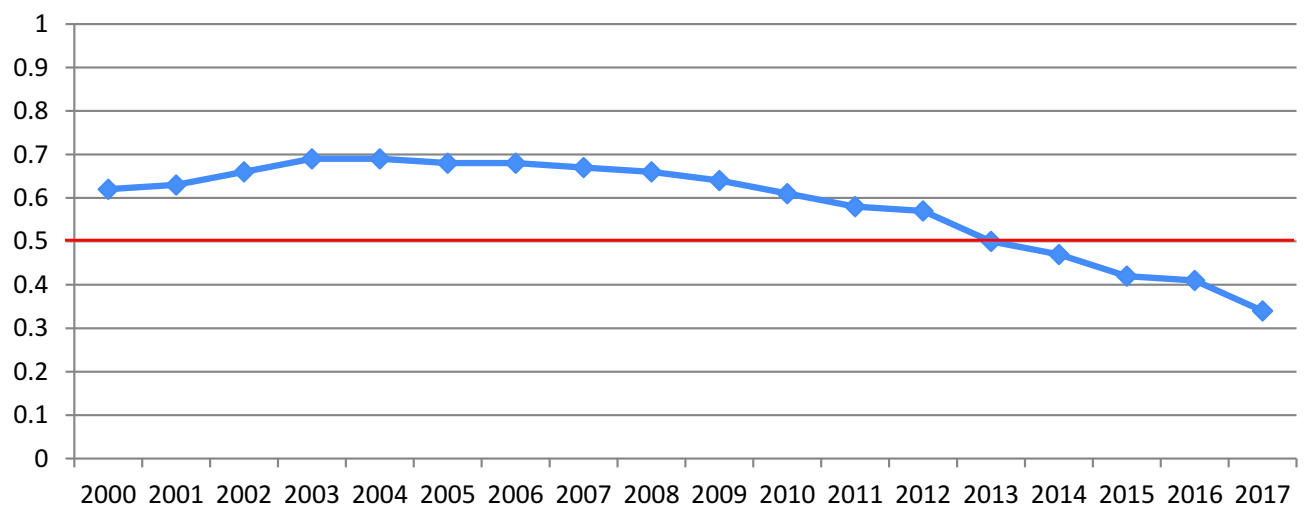

Figure 1. V-DEM electoral democracy index, Turkey 2000-2017.

Source: www.v-dem.net.

enrich Levitsky and Loxton's theoretical contribution testing the capacity of their framework to travel beyond Latin America and explain cases characterized by different conditions (tutelary democracy, relevant role of international factors, etc.). Moreover, this case selection is justified also by the intrinsic relevance of the Turkish case, which may provide crucial information on many sub-fields of research within the democratization theory (Esen and Gümüşçü 2016). For example, being a mid-level income country Turkey represents a critical challenge to the modernization theory, according to which democracies with a non-oil GDP per capita exceeding $\$ 8043$ have never shifted into authoritarianism (Brownlee 2016). It also represents a crucial case in the emerging literature on democratic backsliding caused by elected leaders (Bermeo 2016). Moreover, it provides relevant information on the emergence and durability of hybrid regimes (Levitsky and Way 2010). Furthermore, being subjected to the EU conditionality, the Turkish autocratization challenges the role played by international actors in democratization processes. Finally, Erdoğan's case can be interpreted through the lens of the global phenomenon represented of populism (Yabanci 2016).

The paper is divided into seven sections. After the introduction, the literature on Turkish autocratization will be overviewed. Then, I present the framework connecting populism and competetive authoritarianism. In the fourth section, Erdoğan is classified as a 'movement populist'. An analysis of the processes and causal mechanisms through which he confronted tutelary institutions, taking control of the Turkish state, and triggering the rise of competitive authoritarianism is provided in the fifth section. The last empirical section describes, briefly, the maturation of CA in Turkey. I conclude with the major findings of this research.

\section{Erdoğan and the Turkish autocratization: an overview of the literature}

Since 2002, the literature has widely analyzed Erdoğan's impact on Turkish politics. While some democratic improvements have been initially credited to the AKP (Tuğal 2009), growing concerns about a democratic erosion have emerged since Erdoğan's second term in office (Taş 2015). The recent literature has mainly engaged 
in a taxonomical debate regarding the type of regime established in Turkey, focusing only rarely on the factors explaining this regime change. Hence, several scholars have applied concepts such as illiberal democracy (Bechev 2014; Türkmen-Dervişoğlu 2015), delegative democracy (Özbudun 2014; Taş 2015), electoral authoritarian (Konak and Özgür Dönmez 2015), and competitive authoritarianism (Esen and Gümüşçü 2016; Özbudun 2015). This literature can be clustered into two groups, with one of them still considering Turkey as a diminished form of democracy and the other preferring to opt for sub-categories of authoritarianism. Here, I side with the latter. The V-DEM Electoral Democracy Index, which shows Turkey falling below the democracy threshold (0.5) in 2014, confirms this claim (Figure 1).

Moreover, I share Esen and Gümüşçü’ conclusions (2016), according to which competitive authoritarianism is better equipped to describe the features of Erdoğan's regime respect to any other type of political system. The Authors claim that Turkey transitioned from tutelary democracy to CA since 2010: the end of tutelary democracy in the same period is confirmed by several Turkish scholars (Gürsoy 2012; Kuru 2012; Taş 2015; Yildiz 2014). Then, through a brilliant analysis of the key competitive authoritarian dimensions (elections, civil liberties, and the playing field), they find an almost perfect match between CA and Erdoğan's Turkey. However, as much of the literature on Turkish autocratization, Esen and Gümüşçü have privileged in this article the taxonomical debate about the regime installed by Erdoğan respect to the factors explaining the regime change.

On this regard, the literature proposes very few hypotheses. According to one of them, the emergence of the AKP as a predominant party led the party leadership to adopt a majoritarian interpretation of democracy. In turn, this led to a growing concentration of power and the progressive elimination of checks over it (Gümüşçü 2013; Müftüler-Baç and Keyman 2012). However, electoral hegemony cannot explain by itself autocratization: cases like Japan show that democracy may coexist with a predominant party. Moreover, as stressed by Özbudun (2006) the majoritarian interpretation of democracy was already present in the Welfare party (WP) and others AKP predecessors. Another hypothesis focuses on the existential insecurity of the AKP elite, triggered by the secularist interference in the 2007 presidential elections and the attempt to ban the AKP in 2008. Those events led Erdoğan to adopt a tougher line against oppositions to avoid similar existentialist threats in the future (Öniş 2013). However, focusing just on some key events would miss to evaluate the prolonged process that led to the rise of competitive authoritarianism in Turkey. Yet another thesis focuses on the learning processes of the AKP leadership, which adopted an authoritarian mode of governance similar to that of Kemalists (Keyman and Gümüşçü 2014; Somer 2016). Although there are important similarities between the Kemalist and the AKP modes of governance, this explanation underestimates the crucial innovations introduced by the ruling party since the 2000s. Finally, in a very recent article that explores processes and mechanisms through which the AKP managed to build a pro-government business class, Esen and Gümüşçü (2018) suggest that the AKP-business relations may represent the driving force behind the rise of CA in Turkey. However, this thesis risks to consider as a cause what should be more appropriately evaluated as a means. In fact, both the Levitsky and Way's framework (2010) and the very same analysis conducted by Esen and Gümüşçü underline the instrumental 
nature of the incumbent's favourable treatment of specific business sectors and actors, which were required to pay back the ruling party both during electoral campaigns and in inter-electoral periods. Hence, the competitive authoritarian regime has not been built for enriching and protecting a specific business class, as an oversemplification of Esen and Gümüşçü's thesis would lead to think. On the contrary, these Authors demonstrate that the establishment of a pro-government business block represented an effective tool for preserving political power and assuring the regime's survival. In conclusion, the political dimension appears to be dominant in the Turkish case, and it is in this dimension that we need to look for an explanation of the rise of competitive authoritarianism in Turkey.

Hence, which factors may explain the Turkish autocratization? My claim is that we have to focus on the peculiar interactions among Erdoğan's populism and the domestic and international environments in which he operated.

\section{Populism and competitive authoritarianism}

To explore the relationship between populism and CA, I build upon Levitsky and Loxton's study on Latin America (2013), where they demonstrate how populism may represent a catalyst for the emergence of competitive authoritarianism. The adoption of this framework is justified by the similarities among Turkey and Latin American cases, which are highlighted by an increasing body of literature that compares Erdoğan's populism with South American cases (Aytaç and Öniş 2014; Selçuk 2016; Yabanci 2016). However, while these studies are valuable to understand Erdoğan's leadership style, they do not address the connections between populism and the Turkish autocratization, which give us the chance to test on Turkey the explicative capacity of a framework that does exactly that for the same Latin American countries.

Levitsky and Loxton (2013) compare 14 presidents elected in four Latin American cases (Bolivia, Ecuador, Peru, and Venezuela) between 1990 and 2010. They start their analysis evaluating first other variables that may trigger autocratization processes. Economic crises, mineral rents, economic statism, institutional and democratic fragility and party system weaknesses are all factors that may favour a transition from weak democracies to hybrid or authoritarian regimes (Levitsky and Loxton 2013). In fact, these factors stimulate the concentration of power in the executive by weakening social, institutional and political checks over it. However, according to Levitsky and Loxton none of these variables can explain alone the rise of competitive authoritarianisms because of the excessive number of exceptions: for example, CAs in Bolivia and Ecuador emerged in phases of robust economic growth, Peru became a competitive authoritarian regime before the 2000s mineral boom, the level of statism was more or less constant for all the cases considered, etc. Hence, Levitsky and Loxton's hypothesis is that to explain transitions from weak democracies to CAs other factors must be considered: in Latin American cases this factor is populism (Levitsky and Loxton 2013).

Building on Barr's definition (2009), Levitsky and Loxton identify three characteristics of populism. ${ }^{1}$ First, populists use anti-establishment appeal to garner popular support, positioning themselves in opposition to the entire elite. Second, populists are outsiders, emerging from outside the national party system. Here a caveat is added: 'politicians cease to be outsiders if they have governed previously, served as long-term cabinet ministers, or 
participated in national elections for 10 years or more' (Levitsky and Loxton 2013, 115). Third, populists overcome mediating institutions, like political parties, creating a personalistic linkage with the people. According to Levitsky and Loxton, to have full populism all three characteristics are needed. However, specific sub-types of populism can be detected in cases that possess the anti-establishment appeal, evaluated as the only necessary condition, and one but not both of the other features. Hence, an insider who rely on an anti-establishment appeal and a personalistic linkage is identified as a maverick populist. Alternatively, an outsider who combine the necessary condition with a linkage based on the intermediation of a strong grassroots movement (i.e. Evo Morales) is classified as a movement populist (Levitsky and Loxton 2013).

Despite favouring the inclusion of marginalized groups into the political process, populism may stimulate the transition from a weak democracy to competitive authoritarianism for three main reasons (Levitsky and Loxton 2013). First, due to their outsider status, populists lack skills as negotiation and coalition building, which are acquired spending years working within institutions typical of democracy (i.e. parliaments); moreover, this lack of experience within democratic institutions lead to a weak commitment on the part of populists to preserve those institutions and to pursue their goals through democratic procedures.

Second, populist campaigns establish an 'us' versus 'them' divide, where the 'them' consists of both the old elite, pictured as corrupt and detached from reality, and the state institutions controlled by that elite. Hence, in their campaigns populists often promise to establish a 'real' democracy, ousting old elites and reforming their institutions. Consequently, when populists win elections through an anti-establishment appeal, they earn an electoral mandate to bury the existing elite and its institutions, which cannot be dismantled without threatening the democratic nature of the regime.

Third, once in power populists are confronted by hostile institutions of horizontal accountability still controlled by the old elite. Since populists won elections on the ground of an anti-establishment appeal, in order to fulfil their promises they are incentivized to assault existing democratic institutions, trying to close legislatures, colonizing judiciaries or changing the constitution.

The election of a populist will trigger a constitutional crisis, faced by populists through plebiscitary strategies like referenda, crowded mass rallies, call for early elections for either a new parliament or a constitutional assembly, etc. If populists prevail, they gain an unchecked control over state institutions through radical changes in the constitutions, mass purges and the appointment of loyalists to key public positions. This control of the state apparatus allows populists to skew the playing field against opponents, favouring the rise of competitive authoritarianism (Levitsky and Loxton 2013).

According to Levitsky and Loxton, CA is more probable with full populists, while maverick populists are the least dangerous. In cases of movement populists, accountability mechanisms to strong grassroots movements may prevent an excessive concentration of power. However, they will act as full populists if those movements are themselves anti-establishment.

Finally, the authors stress that populism represents only a proximate cause of competitive authoritarianism, while other factors may also be relevant. However, they claim that only a combination of those conditions with the election of a populist may trigger a transition to CA. Hence, populism represents a catalyst that, with other factors 
acting as facilitating conditions and through the mechanisms described above, may explain the rise of competitive authoritarianism (Levitsky and Loxton 2013).

Levitsky and Loxton do not consider their study as a definitive test of their framework; however, it allows them to show the causal mechanisms at work and provides some initial support for the theory. Hence, some relevant theoretical questions may arise: can this framework travel and explain cases in other regions of the world? How it interacts with conditions absent in Latin American cases? The peculiarities of the Turkish case enrich the original framework providing a possible answer to these questions. For example, international factors (i.e. EU conditionality) played a prominent role in Turkey but were marginal in Latin America: how does Levitsky and Loxton's framework interacts with these factors? Moreover, respect to Latin American cases, the Turkish establishment included autonomous institutional actors with full control of the legal means of coercion (i.e. military) and a recent history of direct intervention in politics: can Levitsky and Loxton's framework be applied in cases of tutelary democracy? Finally, is this framework applicable to countries where religion represents a relevant issue?

Although the research strategy is centred on a structured and focused case study (George and Bennett 2005), Latin American cases will constitute a constant point of reference and comparison. This investigation will follow the structure adopted by Levitsky and Loxton to examine each of their 14 cases. First, I classify Erdoğan as a populist. Then, I explore the processes through which the populist mechanisms, interacting with other factors, allowed him to acquire full control of state institutions. Finally, I describe how Erdoğan has employed those institutions against opponents, skewing the playing field and triggering the emergence of competitive authoritarianism.

Before starting the empirical analysis, I need to stress that this investigation will be mostly centred on the pre-2010 phase. To justify this choice two factors related to Levitsky and Way's CA framework are worth mentioning: first, a competitive authoritarian regime cannot exist if the authority of elected officials is restricted by unelected tutelary powers; second, the presence of just one of the indicators elaborated for each competitive authoritarian dimension (elections, civil liberties, the playing field) is sufficient to score a case as CA (Levitsky and Way 2010). On this ground, the end of tutelary democracy in 2010 was a necessary conditions to classify Turkey as a competitive authoritarianism, despite Esen and Gümüşçü's analysis demonstrated that some of those indicators were present even before 2010 (Esen and Gümüşçü 2016). Therefore, once tutelary democracy ended a CA regime emerged in Turkey, although in an immature and incomplete form, which then fully consolidated during Erdoğan's third term in office. However, if the goal is to explain the rise of competitive authoritarianism in Turkey rather than describing it in its mature form, the analysis has to focus primarily on factors and processes belonging to the pre-2010 phase.

\section{Erdoğan as a peculiar movement populist}

To comprehend Erdoğan's populism and its impact on Turkey, it is crucial to underline first the peculiarities of this case. Unlike Latin American cases, Turkey presented a dual power structure where tutelary veto-players exerted a relevant influence over elected governments. In particular, the military staged several coups since the 1960s, 
accumulating important privileges and veto powers through constitutional and legal regulations (Yildiz 2014). Other important veto-players were the judiciary, with the constitutional court closing Islamist parties several times, and the presidency of the republic. According to Mardin (1973), Turkish politics is built around a strong centre, represented by the state bureaucracy and the military, which are imbued with Kemalist principles. This centre is confronted by a hostile periphery, including the peasantry, small farmers and artisans, and is based on a heterogeneous set of regional, religious and ethnic groups and political interests. The rise of Erdoğan represents the last challenge of these peripheries to the Kemalist state. In fact, the AKP is the last representative of a chain of Islamist parties closed by the constitutional court or the military since the 1970s, as the National Order Party, the National Salvation Party and the WP. After the closure of WP's successor, the Virtue party, in 2001, the reformist wing of the Islamist movement established the AKP under Erdoğan's leadership (Özbudun 2006).

Anti-establishment tendencies characterized all AKP predecessors. For example, in the 1995 WP electoral platform the Turkish system was described as a 'fraud', a 'guided democracy', and the promise to establish a 'real pluralistic democracy', with a greater role for referenda and popular councils, was officially included. Social justice, honest government and the restoration of Turkey's former grandeur were emphasized. While respecting the role of elections as the only route to political power, WP's idea of democracy was more majoritarian than liberal or pluralistic. In fact, democracy represented the means to reach the real goal, that 'order of happiness' constituting a reference to the Islamic routes of the party. While WP' claims regarding the establishment of an Islamic state based on Sharia were vague, its promises to enhance freedom of conscience, implying the right to live according to one's beliefs, constituted a source of conflicts with the establishment. On the economy, an Islamicinspired 'just order', that would have implied heavy state control, was promoted. On foreign policy, the WP was thirdworldist, advocating closer relations with Islamic countries, antiAmerican and clearly opposed to the EU accession process (Özbudun 2006).

Events like the 1997 'post-modern coup', the closure of the WP by the constitutional court in 1998 or, perhaps even more, Erdoğan's personal experience, ${ }^{2}$ had a crucial impact on his choices, convincing him to confront tutelary institutions via more pragmatic strategies (Selçuk 2016) and, hence, leading to a partial karstification of his anti-establishment appeal. In fact, if in 1993 Erdoğan could say that 'there is no room for Kemalism or any other official ideology in Turkey's future' and democracy is 'a vehicle which you ride as far as you want to go and then get off', (Jenkins 2008, 166) in 2001 Erdoğan and AKP' positions became more moderate. The AKP leadership defined itself as conservative democrats, although Islamist origins were not officially repudiated. Moreover, it formally abandoned the WP ideological combativeness, adopting a different programmatic platform. For example, it refrained from launching populist attacks against the establishment and pledged to respect secularist principles in religious affairs (Özbudun 2006). On the economy, it embraced neo-liberalism, while on foreign policy it was pro-USA and supported the EU accession process (Dinçşahin 2012).

However, Erdoğan's anti-establishment appeal did not disappear, also because of the propitious situation generated by a severe economic crisis. According to the V-DEM GDP Growth Index in 1999 and 2001 the GDP suffered a decline of 4.94\% and 7.18\%, 
respectively. This economic crisis represented a crucial facilitating condition for Erdoğan's rise to power, since it led people to lose faith in mainstream political parties: none of the six parties present in parliament passed the $10 \%$ electoral threshold in the 2002 elections (Çarkoğlu 2002). Hence, thanks to the economic crisis and the loss of credibility suffered by traditional political parties, during the 2002 campaign Erdoğan could effectively resort to an anti-establishment appeal. He contrasted 'the people' and 'the elite' in his rallies, presenting himself as a 'man of the people', a 'black Turk', referring to his poor socio-economic background and claiming to represent all the disadvantaged groups identified as 'the periphery' (Çinar and Sayin 2014). The use of these kind of narratives as legitimation tools is common not only in the LA cases analyzed by Levitsky and Loxton (2013), but also in other EU candidate countries like Macedonia and Serbia (Günay and Dzihic 2016; Yabanci and Taleski 2018). These antiestablishment stances in the Turkish case are exemplified by the following quotation from an Erdoğan's rally:

My story is the story of this people. Either the people will win and come to power, or the pretentious and oppressive minority - estranged from the reality of Anatolia and looking over it with disdain - will remain in power. The authority to decide on this belongs to the people. Enough is enough, sovereignty belongs to the people! ${ }^{3}$

As confirmed by Aytaç and Öniş (2014), respect to the national party system and the secularist establishment, Erdoğan was an outsider. During the 1990s, he was not part of the mainstream political community, although in 1995 he became mayor of Istanbul. Moreover, in 1998-1999, Erdoğan's imprisonment for reciting a poem with militant Islamist tones reinforced his outsider status: because of this sentence, he was temporarily banned from politics (Aytaç and Öniş 2014). This political experience can be compared to that of Morales or Correa: the former was elected to Congress in 1997 and participated in 2002 presidential elections before taking power in 2005; the latter served as finance minister in 2005 before winning elections in 2006 (Levitsky and Loxton 2013). However, neither Erdoğan nor Morales or Correa had participated in national electoral politics for more than a decade, as prescribed by Levitsky and Loxton to be coded as an insider. Hence, all of them can be scored as outsiders.

With regard to the type of linkage, Erdoğan is closer to Morales rather than Fujimori or Correa. Just as the Bolivian Movement Toward Socialism (MAS), which emerged from the autonomous coca growers' movement (Levitsky and Loxton 2013), the AKP was an active political party, not Erdoğan's electoral machine (White and Herzog 2016). His linkage to supporters was, then, more participatory than personalistic, although the AKP, as the MAS, began to undergo a strong personalization of power in the 2010s (Taş 2015).

In conclusion, in 2002 Erdoğan was a movement populist, very similar to Morales, since both lacked a full personalistic linkage. However, he was a peculiar movement populist because of the partial and strategic moderation of his antiestablishment appeal, determined by a different incentive structure respect to the Bolivian case. 


\section{Conquering the Turkish state: from a defensive to an offensive strategy}

After a severe economic crisis and the collapse of the party system facilitated Erdoğan's rise to power, the pattern highlighted by Levitsky and Loxton (2013) did not emerge immediately, because of the different conditions present in Turkey respect to Latin American cases. Due to the threat represented by tutelary institutions, which could realistically ban the party or its leader from politics (Judiciary) or overthrow the government (Military), Erdoğan's main goal was survival. Hence, during his first term in office, instead of launching plebiscitary attacks on the old elite and its institutions of horizontal accountability, risking to trigger an institutional crisis difficult to win, Erdoğan adopted a defensive strategy, refraining from open conflict on religious issues, and fostering both economic development and the EU accession process (Çarkoğlu 2007; Taş 2015; Yabanci and Taleski 2018). The core of this strategy was Erdoğan's alliance with foreign forces (EU), which legitimated him internally and internationally, allowed him to fight the establishment without resorting to dangerous plebiscitary strategies, and shielded his government against any radical intervention by the Kemalist state (Tocci 2005). The very same strategy, which resorted to EU-sponsored reforms to increase the government legitimacy and to weaken internal veto-players, was evident in other EU candidate countries like Serbia and Macedonia (Cengiz Günay and Dzihic 2016).

The effectiveness of this strategy was enhanced by an important facilitating condition, the partial moderation of the military elite, which was influenced by the following factors: the lack of western support (Akkoyunlu and Öktem 2016); the risk of intervening directly in politics during a dire economic crisis and failing to solve it; the recent moderate support of the military for the EU integration process and the reforms it required, including the weakening of its tutelary powers (Gürsoy 2012).

Under the sponsorship of the EU, Erdoğan could initially pass unprecedented reforms that weakened the military, increasing the number of civilian members in the National Security Council, reducing the frequency of its meetings and degrading its decisions to simple recommendations. Moreover, the seats reserved to the military in the Council of Higher Education and the Radio and Television Supreme Council were taken out, and the EMASYA protocol, which allowed the military to bypass civilian authorities in responding to social incidents, was annulled (Gürsoy 2011; Yildiz 2014). Hence, initially Erdoğan's fight against the establishment improved the quality of Turkish democracy, thanks to the EU-sponsored civilianization of politics.

After 2005, the EU accession process started to lose its dynamism, with several European leaders objecting to Turkish membership. Consequently, the crucial source of legitimacy and protection the EU had represented for Erdoğan quickly weakened, leaving the government in an environment where tutelary institutions were still powerful. During his first term in office, the establishment forced Erdoğan to step back from many reforms, such as those related to the higher education system and the secondary education, the reform of the public administration and the proposal to subject the decisions of the Higher Military Council to civilian courts. Other examples can be drawn from the relationship between Erdoğan and the secularist President Ahmet Necdet Sezer, who continuously blocked government appointments to top bureaucratic positions and frequently vetoed important pieces of legislation (Çarkoğlu 2007). 
Such conflicts made the AKP the party in power, but not of power, putting at risk Erdoğan's ability to fulfil his electoral promises, and allowing him to keep at least part of its outsider status and the legitimacy to resort to an anti-establishment appeal. This confrontation became critical with the 2007 presidential elections, which put Erdoğan's political future at risk and led to an institutional crisis similar, yet more moderate, to those identified by Levitsky and Loxton in Latin America. These elections led Erdoğan to unveil its populism, allowing the mechanisms highlighted by Levitsky and Loxton to emerge and manifest their effects. Hence, plebiscitary strategies similar to those adopted by Morales and Correa (i.e. early elections, referenda, etc.) were used by Erdoğan to deal with the establishment during and after this institutional crisis. The result, as in Latin American cases, was the conquest by Erdoğan of a stronger control over crucial state institutions, and the deployment of those institutions against opponents, which skewed the playing field and led to the rise of competitive authoritarianism in Turkey.

According to formal procedures and established practices (Çarkoğlu 2007), Erdoğan could have elected an AKP president quite easily in 2007 (Dinçşahin 2012), acquiring full control of the last secularist bastion in the executive. Moreover, given the presidential appointment powers, the AKP could have intensified its penetration of state institutions (Dinçşahin 2012; Gümüşçü 2013). Finally, and more importantly, the failure to elect one of its members would not have played well in the upcoming general elections, seriously damaging Erdoğan's chances to win them and, hence, putting at risk his political future (Çarkoğlu 2007).

From the opposition's angle, an AKP president constituted a real threat, since a crucial republican institution would have fallen under the Islamist control. Hence, they insisted on the selection of a secularist candidate (Çarkoğlu 2007). Erdoğan showed no interest in finding a compromize (Çarkoğlu 2007) and selected Abdullah Gül, whose wife wore a headscarf, as the AKP candidate (Grigoriadis 2009).

The secularist reactions were intense, triggering a dangerous institutional crisis and stressing what an existential threat they still represented for Erdoğan's political future. Pro-Kemalist media and civil society organizations objected strongly to the candidacy, organizing crowded mass demonstration in the major cities (Grigoriadis 2009). Moreover, on 27 April the military issued a statement, which appeared on the General Staff's website, known as the 'e-coup', criticizing the Islamist tendencies within the government and warning that the military stood ready to protect Kemalism (Çarkoğlu 2007; Grigoriadis 2009). Finally, the secularist Republican People's Party (Cumhuriyet Halk Partisi, CHP) appealed to the constitutional court claiming that the quorum for the election of the president by the parliament was not reached due to its own boycott of the presidential elections. On 1 May, with a dubious decision from a legal point of view, the court approved the appeal (Kalaycığlu 2012). At the political level, this decision showed that the judiciary had joined the military in its opposition to Erdoğan, since it made legally impossible the election of an AKP president (Grigoriadis 2009).

Erdoğan reacted passing on the offensive with the adoption of the strategies and mechanisms stressed by Levitsky and Loxton. He issued a counter-statement reminding the military that his government represented the civilian authority and that, in democracies, it is unacceptable for the armed forces to intervene in politics (Çarkoğlu 2007). More importantly, anti-establishment discourses became dominant in Erdoğan's rhetoric, with accusations to the military, the president, the CHP and the constitutional court 
to be part of 'the elite' as opposed to 'the people', represented by the AKP (Dinçşahin 2012). Furthermore, Erdoğan proposed a constitutional amendment for direct presidential elections that was later submitted to a referendum in order to override the presidential veto. Finally, he called for an early election framing the electoral campaign as a fight of 'the people' who, voting for the AKP, could defeat 'the elite', which was hindering the will of the people's rule over the country (Dinçşahin 2012). Thus, in 2007 parliamentary elections Secularism and the nature of the regime were the dominant issues (Grigoriadis 2009).

In these elections, the AKP passed from 34\% (2002) to an astonishing 47\%, giving Erdoğan a clear electoral mandate and the popular legitimation to confront and domesticate the establishment, in line with Levitsky and Loxton's framework (2013). A step in this direction was Gül's election to the presidency, which gave Erdoğan full control of the executive. The victory (70\%) in the 2007 referendum on direct presidential elections represented a new boost in Erdoğan's growing confidence.

In 2008, two decisions of the constitutional court demonstrated the existential threat constituted by the institutions of horizontal accountability for Erdoğan's political survival and his capacity to fulfil his electoral promises: the lift on the headscarf ban in universities adopted in 2007 was ruled out, and the AKP was almost banned as a centre of anti-secular activities (Kalaycıŏlu 2012).

Starting from 2008, a series of court cases led to the unprecedented arrest of retired generals, judges, prosecutors, journalists, businessmen, etc. According to the accusations, they belonged to the 'Ergenekon' organization, which had the aim of staging coups against the government (Gürsoy 2011; Kalaycığlu 2012). When Erdoğan declared that he was the prosecutor of the Ergenekon trials, and the CHP leader, Deniz Baykal, responded that he was the barrister for the defendants, it became clear that the these trials had come to be part of the political fight between the AKP and the establishment (Kalaycioğlu 2012). In Erdoğan's rhetoric, these cases became evidence for the obstruction of the national will by the elite or 'the enemies of national sovereignty', as they were depicted by the AKP (Dinçşahin 2012). More importantly, according to Esen and Gümüşçü (2016) Erdoğan used courts controlled by the Gulenists against opponents in the armed forces through fabricated evidences and violations of due process, leading opposition parties, intellectuals and journalists to denounce them as 'political trials', to be considered more as a tool to intimidate any kind of AKP opponent (Akkoyunlu and Öktem 2016; Dinçşahin 2012; Gürsoy 2011). The main result of these trials was a drastic delegitimation of the political role of the military in Turkey (Taş 2015).

Despite these trials demonstrated Erdoğan's capacity to use the judiciary against his opponents, this crucial secularist institution was still not under his full control. Hence, in 2009, triggered by rumours about another closure case against the AKP (Kalaycioğlu 2012), which again underlined the threat represented by the institutions of horizontal accountability, Erdoğan decided to assault this crucial branch of the state administration with a judicial reform to be submitted to a popular referendum. Only two out of 26 amendments stimulated an intense debate, since they were meant to restructure the constitutional court and the high council of judges and public prosecutors (Hâkimler ve Savcılar Yüksek Kurulu, HSYK), enlarging their ranks and setting new selection procedures (Kalaycıoglu 2012). According to the oppositions, these amendments would put 
the judiciary under Erdoğan's control since the AKP could pack both organs with loyalists. ${ }^{4}$ The amendments were voted in parliament by the AKP majority and then submitted to a referendum. Erdoğan employed again a populist anti-establishment appeal, which divided the society between 'the people' supporting the reform and 'the elite' opposing it (Dinçşahin 2012). He presented the reform as a new tool to empower the nation and to hold secularists accountable (Kalaycioğlu 2012). He depicted the opposition as a 'coalition of evil', which could not agree on any issue except the fight against the amendments that would make 'the people' stronger (Dinçşahin 2012).

On 12 September 2010, Erdoğan won the referendum (58\%), gaining another crucial electoral victory. The fears of the opposition materialized soon, since the majority of the new constitutional judges was conservative and the new members of the HSYK were all included in a list unofficially circulated by the Ministry of Justice before the election (Keyman and Gümüşçü 2014). In fact, the new HSYK relocated all the judges and prosecutors whose decisions were not in line with the government wishes (Kalaycioğlu 2012).

In conclusion, the processes just described sanctioned the end of tutelary democracy in Turkey by 2010. First under the sponsorship of the EU and through more conventional tools, and then under a clearer electoral mandate and through typical populist strategies, Erdoğan gained a greater control of crucial state institutions, including those of the horizontal accountability, which lost to a good extant their capacity to act as checks and balances over the executive. During its third term in office, Erdoğan deployed more frequently and systematically state institutions against opponents, leading to the consolidation of already emerged competitive authoritarian tendencies.

\section{Consolidating competitive authoritarianism in Turkey}

Since 2011, the maturation of Erdoğan's populism further contributed to the consolidation of the Turkish CA. Next to his anti-elite stance, which remained one of the key features of Erdoğan's appeal despite the two terms in office, an anti-pluralist posture, already (re)-emerged after 2007, further consolidated, becoming a defining characteristic of his populism (Çinar and Sayin 2014). Hence, Erdoğan's conception of democracy returned to be almost as majoritarian and plebiscitarian as that of the WP (Çinar and Sayin 2014; Özbudun 2006, 2014).

As the party has grown stronger electorally, Erdoğan emphasized more and more the support of the 50\% behind him, discrediting the other 50\% (Çinar and Sayin 2014). The 'us' versus 'them' divide was reconstructed drawing a sharp contrast between the 'old Turkey', described as an era of coalition governments, tutelage, poverty, and corruption, and the 'new Turkey', painted as the golden era of single-party governments, advanced democracy, wealth, and accountability (Yabanci 2016; Yabanci and Taleski 2018). All kind of oppositions were attacked as enemies of the nation, representative of the old Turkey, and mouthpieces of the secularist establishment (Taş 2015; Yabanci 2016).

This majoritarian and plebiscitarian approach to democracy led Erdoğan to privilege, as instruments of accountability and source of legitimacy, direct and unmediated links with the people (i.e. elections, referenda, crowded mass rallies) respect to the string of democratic checks and balances (Selçuk 2016). According to Erdoğan, the bureaucratic oligarchy, the judiciary and the separation of powers had become impediments for the AKP, which was the only one who could realize the people's will (Yabanci 2016). 
This anti-pluralism was also applied to power relations within the party. In 2001, the AKP was basically controlled by Erdoğan, Gül and Arýnç. In the following years other relevant figures emerged within the party, as Babacan, Davutoğlu, Şener, Coşkun, Aksu. In the last decade, Erdoğan managed to sideline all these important AKP leaders. For example, as President of the Republic Gül was meant to cut his ties with the party, which he did to a considerable degree, allowing Erdoğan to purge his supporters from the AKP structure and exclude them from the parliament, handpicking all candidates since the 2011 elections (Taş 2015). Moreover, in order to prevent the return of Gül to the party as a leader, Erdoğan held an extraordinary party congress one day before the end of Gül's presidential mandate (Akkoyunlu and Öktem 2016). Thanks to these and other strategies, like hiring numerous advisors and using some of them to control cabinet ministers (Akkoyunlu and Öktem 2016), Erdoğan was able to take full control of the party, and, just as Morales in Bolivia, to acquire an increasingly personalistic linkage with his supporters: the AKP became subjected to a one-man rule, with the party cadres cleansed of alternative voices and organized according to perceived loyalty to the leader (Taş 2015).

The strengthening of Erdoğan's populism further intensified the concentration of power in his hands, as well as his unchecked control over state institutions, which were increasingly employed against oppositions. These processes led to the consolidation of crucial shortcomings in each of the competitive authoritarian dimensions (elections, civil liberties, and the playing field) elaborated by Levitsky and Way (2010). In what follows, I underline just some key aspects, since an exhaustive analysis of these dimensions can be found in Esen and Gümüşçü's article (2016).

While elections were the least affected dimension, violations of civil liberties were increasingly frequent and intense, as demonstrated by the declining trends of the V-DEM Civil Liberties and Expanded Freedom of Expression indexes (Figure 2).

As, for example, in the competitive authoritarian regime established by the Bolivian President Morales, journalists have been heavily harassed in Erdoğan's Turkey: between 2003 and 2015, 63 journalists have been sentenced to a total of 32 years in prison.

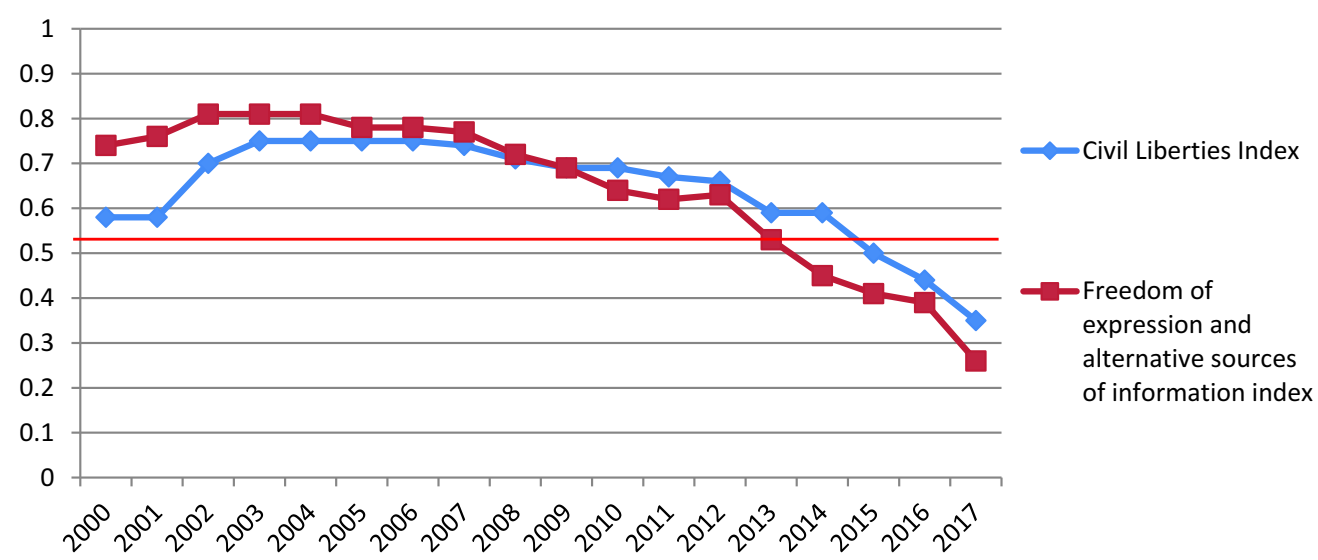

Figure 2. V-DEM civil liberties and freedom of expression and alternative sources of information indexes, Turkey 2000-2017.

Source: www.v-dem.net. 
Under the 2006 law on anti-terrorism, 33 journalists were sentenced to more than 365 years in prison (Esen and Gümüşçü 2016). During Erdoğan's third term in office, Turkey has become the top jailer of journalists in the world (Corke et al. 2014).

The 2013 Gezi park protest represents a major example of civil liberties violation. Started with the aim of preserving Gezi Park against a government-sponsored project to build in its place a reconstruction of the Taksim military barracks and a shopping mall, the protests gained soon an anti-government orientation, which led to a brutal repression by the police with six deaths and thousands of injured people (Amnesty International 2013).

Crucial violations of the playing field dimension were also present. For example, the access to the law was unbalanced. Erdoğan's struggle to establish his control over the judiciary culminated with the 2010 constitutional reform, which allowed him to pack the HSYK with members of the allied Gülen movement (Keyman and Gümüşçü 2014). As soon as the common enemy, the military, was sidelined the AKP-Gülen alliance unraveled, transforming the judiciary yet again in a threat for the government: in 2013 several corruption investigations were launched against AKP ministers and even Erdoğan's own family. With the introduction of a new legislation in 2014 Erdoğan was able to close those investigations, purge the judiciary from gülenists and reaffirm his control over this crucial institution (Müftüler-Baç 2016; Özbudun 2015).

With regard to the media access, Erdoğan enjoyed a disproportionate and biased coverage by the state-owned Turkish Radio and Television during all the recent elections. Moreover, private media were packed or bullied by the AKP, leading to the consolidation of a pro-government media bloc (Yllmaz 2016).

The access to resources was also uneven. Beyond Erdoğan's abuse of public funds in all recent elections (OSCE/ODIHR 2015), he also used private resources to gain a competitive advantage vis-à-vis the oppositions. During the 2000s, Erdoğan used public policy instruments to favour the emergence of politically created business actors through nepotistic practices in several economic sectors. In return, the favoured entrepreneurs supported heavily the ruling party (Esen and Gümüşçü 2018; Adaman et al. 2018Forthcoming; Buğra and Savaşkan 2014; Taş 2015).

The violations in all competitive authoritarian dimensions have been exacerbated AQ3 after the 2016 coup attempt (Esen and Gümüşçü 2017a; Öktem and Akkoyunlu 2016), which represented the seventh attempted military intervention in politics since the 1950s (Esen and Gümüşçü 2017a). The coup's failure is explained by the lack of organization and support for the putschists and by Erdoğan's capacity to call on his own supporters and deploy them in his defence (Esen and Gümüşçü 2017a). The immediate consequences were dire, with 265 people dead and more than 2.000 injured (Schenkkan 2017). Erdoğan reacted imposing a state of emergency that suspended the rule of law and the European Convention of Human Rights and created the legal backdrop for comprehensive purges targeting all kinds of dissent, including from those with not even a nominal connection to the Gülen movement, identified by the regime as the official culprit (Öktem and Akkoyunlu 2016). After one year, the results were shocking: 50,546 people in jail, 103,824 dismissed from public service and 33,843 suspended, 166 journalists in custody, hundreds of lawyers arrested, more than $\$ 10$ billion worth of private companies seized, 150 media outlets and over 1,000 NGOs and foundations closed by decree (Schenkkan 2017). Despite 
siding unequivocally with the government, the oppositions were hit hard: for example, the two leaders and nine parliamentarians of the HDP were jailed, as well as an important leader of the major opposition party, the CHP; dozens of elected mayors in Kurdish municipalities were suspended and replaced with AKP appointees (Öktem and Akkoyunlu 2016; Schenkkan 2017). In conclusion, the coup attempt represented in Erdoğan' words a 'gift from God' (Esen and Gümüşçü 2017a) since it boosted the government support and it gave to Erdoğan the opportunity to crackdown on all kinds of dissent. On the other hand, it had dire consequences on state effectiveness, since the purged Gülenists were substituted by far less skilled loyalists (Akkoyunlu and Öktem 2016).

Another major consequence of the 2016 coup was the opportunity seen by Erdoğan to adopt a constitutional reform transitioning Turkey towards 'ultra-presidentialism' or 'presidential system a la turca' (Taş 2015, 780). Being an Erdoğan's goal at least since 2010, the post-2016 coup situation was perfect for passing this reform, due to the unprecedented support for the government and the weaknesses of all kind of oppositions. The amendments were approved by the parliament in January 2017 and submitted to a referendum (16 April). Despite its advantage in media, money, and resources, and the extensive powers coming from the state of emergency, Erdoğan was barely able to win the referendum $(51,41 \%)$, and perhaps thanks only to the SEC's decision to count votes casted on irregular ballots made the same day of the vote (Esen and Gümüşçü 2017b; OSCE/ODIHR 2017; Schenkkan 2017). This result, widely contested at both domestic and international levels, highlights that the extensive purges conducted during the 2016 and 2017 and the worsening economic conditions have quickly eroded the immense support gained by Erdoğan after the coup. This decreasing support for the regime emerged also in the snap presidential and parliamentary elections held the 24 June 2018. Erdoğan was reelected President in the first round (52.59\%) and could maintain the majority in parliament (344 out of 600) only thanks to the alliance with the nationalist MHP: in fact, the AKP lost 7\% of the vote (42.56\%) respect to the 2015 parliamentary elections, being the only party to loose seats despite the new parliament passed from 550 to 600 members.

Despite all the consequences of the 2016 coup attempt had no role in explaining the rise of competitive authoritarianism in Turkey, they clearly favored its strengthening and were, perhaps, responsible for the emergence of even more hegemonic tendencies in the Turkish political regime (Esen and Gümüşçü 2017a, 2018).

\section{Conclusion}

The main goal of this research was to explain the rise of competitive authoritarianism in Turkey. I started the analysis by sharing Esen and Gümüşçü' findings (2016) according to which Erdoğan's Turkey transitioned from tutelary democracy to competitive authoritarianism since 2010. Focusing on the taxonomical debate about the type of regime installed by Erdoğan, their study is complementary to mine since my analysis focuses on the factors explaining this regime change.

To explain Turkish descent into CA I applied Levitsky and Loxton's framework (Levitsky and Loxton 2013), according to which the election of a populist in the top executive position represented an effective catalyst for the rise of competitive 
authoritarianism in Latin America. The analysis demonstrated the efficacy of this framework in highlighting the processes and mechanisms leading to the rise of CA in Turkey. However, a set of peculiar conditions led to the emergence in the Turkish case of a slightly different pattern respect to the one described by Levitsky and Loxton.

As for many Latin American cases, populism represented only a catalyst for the rise of competitive authoritarianism, since several facilitating conditions and intervening factors were present also in the Erdoğan's case. The economic crisis and the consequent collapse of the Turkish party system were two of them, which contributed heavily to Erdoğan first electoral victory in 2002. While in many Latin American cases the election of a populist triggered a constitutional crisis almost immediately, in Turkey this crucial event was delayed. The realistic threat represented by tutelary institutions, despite the partial moderation of the military elite, and the opportunity represented by the EU accession process, which allowed Erdoğan to fight the establishment through more legitimate means, led him to repress partially and temporarily his populist tendencies, renouncing once in power to launch plebiscitary attacks on the old elite and its institutions of horizontal accountability. During Erdoğan's first term in office the establishment exerted to a good extent its veto powers, leading to a confrontation that reached a critical point with the 2007 presidential elections, which triggered an institutional crisis similar to those identified by Levitsky and Loxton. Since after 2005 the EU accession process had lost much of its dynamism, as well as the protection and legitimacy it had initially provided to Erdoğan, in order to deal with this institutional crisis he unveiled his populism and resorted to the populist strategies and mechanisms highlighted by Levitsky and Loxton. The fight against the establishment led Erdoğan to use plebiscitary strategies similar to those adopted in many Latin American cases (antiestablishment appeal in electoral campaigns, referenda, politicization of the judiciary, etc.), in order to attack and colonize crucial state institutions, including those of the horizontal accountability. In fact, as foreseen by Levitsky and Loxton's framework, Erdoğan gained the electoral mandate to fight and domesticate the establishment with the astonishing victory in the 2007 parliamentary elections, which were followed by the conquest of the presidency with the election of an AKP president, the end of a decisive political role for the military through the politicization of the judiciary in the Ergenekon trials, and an even more consistent colonization of the judiciary thanks to the 2010 constitutional reform passed through a popular referendum. At this point, the main institutions of horizontal accountability had lost their capacity to act as checks and balances over the executive. The colonization of these institutions and their deployment against all kind of oppositions led to the rise of competitive authoritarianism in Turkey.

Two main factors, which are interconnected but need to be evaluated separately for theoretical and analytical reasons, acted as incentives and motivations for Erdoğan to acquire an unchecked control over state institutions and increasingly deploy them against all oppositions. The first is clearly described in Levitsky and Loxton's framework: as in many Latin American cases, Erdoğan needed to override the veto powers of the establishment and its institutions of horizontal accountability in order to fulfill his electoral promises and assure his political future. Hence, on the ground of an electoral mandate to fight and domesticate the establishment obtained in 2007 he attempted and, to a large extent, succeeded in removing permanently those constraints on his power, and used those institutions against whomever could pose a similar threat in the future, favouring in this way the emergence of competitive authoritarianism. 
The second factor emerges clearly in the Turkish case, it is to a great extent valid also for several Latin American cases, but it is only implicitly considered in Levitsky and Loxton's framework: this factor is represented by the insecurity typical of weak democracies. In fact, if in consolidated democracies political competitors see each other as adversaries, which will lose only their public positions in case of electoral defeat, in weak democracies a game dominated by an 'all or nothing' logic is far more probable, in which political opponents consider each other as enemies and election losers may risk also their civil liberties, political rights and even their lives. Turkey is, in this regard, a crucial case since tutelary institutions have always represented an existential threat for Islamist parties, which were repeatedly banned and ousted from power even in the very recent past. The institutional crisis triggered by the 2007 presidential election, with in particular the 'e-coup' attempted by the military, the almost successful attempt by the constitutional court to ban the AKP in 2008 and the rumours that another closure case would be opened in 2009, represented for Erdoğan further incentives to assault those institutions, colonize them and deploy them against opponents to prevent similar threats in the future. Moreover, Erdoğan' violations of elections, civil liberties and the playing field made the option of losing power increasingly riskier since the new government could try to hold him accountable even using the same institutions and undemocratic strategies. Hence, this kind of insecurity complete Erdoğan' motivations and incentives foreseen by Levitsky and Loxton's framework to colonize state institutions and use them to skew the playing field, explaining in this way the rise of CA in Turkey.

Some aspects related to the interactions between tutelary democracy and Levitsky and Loxton's framework need to be further highlighted, since they represent an important contribution to this theory provided by the Turkish case. First, the existential threat represented by tutelary institutions may convince populists to strategically moderate their anti-establishment appeal in order to gain power; second, even once in power populists may decide to delay the showdown with the establishment, waiting for more propitious conditions, without necessarily suffering a loss of popular support as in the case of the Ecuadorian President Bucaram; third, since the establishment includes also autonomous state institutions, populists may be able to keep at least part of their outsider status and the capacity to resort to an anti-establishment appeal even if they are already in power.

The international dimension is not evaluated in Levitsky and Loxton's framework. However, the Turkish case shows how this factor may have a relevant impact on the relationship between populism and the rise of competitive authoritarianism. In fact, the EU integration process contributed to both the initial strategic moderation of Erdoğan and the delayed emergence of the processes foreseen by Levitsky and Loxton. It is important to note that while fostering democracy was among the official goals of the EU accession process, the unintended result has been to contribute to the rise of competitive authoritarianism in Turkey, supporting a leader far less democratic than expected and weakening those institutions (i.e. the military) that had prevented the emergence of such leaders in the past.

In conclusion, this analysis has proved that Levitsky and Loxton's framework may travel and explain the emergence of CAs in other regions of the world, even in cases where the secular/religious divide represents a relevant issue. Despite the presence of partially different conditions, which determined some differences in the ways in which 
Levitsky and Loxton's theory operated in the Turkish case, populism, and its interac- 725 tions with a set of facilitating conditions, represented an effective catalyst for the rise of competitive authoritarianism in Turkey.

\section{Notes}

1. I adopt this definition with due respect to the many others elaborated by the literature, because it is directly related to my research question.

2. In 1998, Erdoğan was sentenced to 10 months in prison and banned from politics for reciting a poem with militant Islamist tones (Selçuk 2016).

3. Cited in Yabanci (2016).

4. The constitutional reform afforded to institutions firmly under AKP control (Presidency and Parliament) more power to appoint senior judges and prosecutors (Taş 2015).

\section{Disclosure statement}

AQ5 No potential conflict of interest was reported by the author.

\section{Funding}

This work was supported by the Fundação para a Ciência e Tecnologia [SFRH/BPD/101442/2014 and UID/SIC/50013/2013]

\section{Notes on contributor}

Antonino Castaldo is a Post-Doctoral Research Fellow at the Institute of Social Science, University of Lisbon. He has a $\mathrm{PhD}$ in Political Science from the University of Florence. He was a Teaching and/or Research Assistant at the University of Science Po (Paris), University of Roma Tre, Luiss University (Rome), and University of Oxford. He is currently working on autocratization processes, with specific reference to the diffusion of competitive authoritarian regimes, and a focus on the Balkan region and the Middle East. He has published articles, book chapters and a book in Italian, English and Portuguese.

\section{ORCID}

Antonino Castaldo (D) http://orcid.org/0000-0003-2943-9853

\section{References}

Adaman, F., M. Arsel, and B. Akbulut. 2018. Neoliberal developmentalism, authoritarian populism, and extractivism in the countryside: The soma mining disaster in Turkey. The Journal of

AQ6 Peasants Studies. doi:10.1080/03066150.2018.1515737

Akkoyunlu, K., and K. Öktem. 2016. Existential insecurity and the making of a weak authoritarian regime in Turkey. Southeast European and Black Sea Studies 16, no. 4: 505-27. doi:10.1080/14683857.2016.1253225

Amnesty International. 2013. Gezi park protests brutal denial of the right to peaceful assembly in Turkey. October 2. www.amnesty.org/en/documents/EUR44/022/2013/en/. 
Aytaç, S.E., and Z. Öniş. 2014. Varieties of populism in a changing global context: The divergent paths of Erdoğan and Kirchnerismo. Comparative Politics 47, no. 1: 41-59. doi:10.5129/ 001041514813623137

Barr, R.R. 2009. Populists, outsiders and anti-establishment politics. Party Politics 15, no. 1: 29-48. doi:10.1177/1354068808097890

Bechev, D. 2014. Turkey's illiberal turn. Policy brief, European Council on Foreign Relations, London. www.ecfr.eu/publications/summary/turkeys_illiberal_turn314.

Bermeo, N. 2016. On democratic backsliding. Journal of Democracy 27, no. 1: 5-19. doi:10.1353/ jod.2016.0012

Brownlee, J. 2016. Why Turkey's authoritarian descent shakes up democratic theory. Washington Post, March 26. www.washingtonpost.com/news/monkey-cage/wp/2016/03/23/why-turkeysauthoritarian-descent-shakes-up-democratic-theory/?utm_term=.64d27062d459.

Buğra, A., and O. Savaşkan. 2014. New capitalism in Turkey - The relationship between politics, religion and business. Northampton, MA: Edward Elgar.

Çarkoğlu, A. 2002. The rise of the new generation Pro-Islamists in Turkey: The justice and development party phenomenon in the November 2002 elections in Turkey. South European Society and Politics 7, no. 3: 123-56. doi:10.1080/13608740708539636

Çarkoğlu, A. 2007. A new electoral victory for the 'Pro-Islamists' or the 'New Centre-Right'? The justice and development party phenomenon in the July 2007 parliamentary elections in Turkey. South European Society and Politics 12, no. 4: 501-19. doi:10.1080/13608740701731457

Cengiz Günay, C., and V. Dzihic. 2016. Decoding the authoritarian code: Exercising 'legitimate' power politics through the ruling parties in Turkey, Macedonia and Serbia. Southeast European and Black Sea Studies 16, no. 4: 529-49. doi:10.1080/14683857.2016.1242872

Çinar, M., and Ç. Sayin. 2014. Reproducing the paradigm of democracy in Turkey: Parochial democratization in the decade of justice and development party. Turkish Studies 15, no. 3: 365-85. doi:10.1080/14683849.2014.954743

Corke, S., A. Finkel, D.J. Kramer, C.A. Robbins, and D. Schenkkan. 2014. Democracy in Crisis: Corruption, Power and Media. Washington D.C.: Freedom House. https://freedomhouse.org/ sites/default/files/Turkey\%20Report\%20-\%202-3-14.pdf.

Dinçşahin, Ş. 2012. A symptomatic analysis of the justice and development party's populism in Turkey, 2007-2010. Government and Opposition 47, no. 4: 618-40. doi:10.1111/j.14777053.2012.01377.x

Esen, B., and Ş. Gümüşçü. 2016. Rising competitive authoritarianism in Turkey. Third World Quarterly 37, no. 9: 1581-606. doi:10.1080/01436597.2015.1135732

Esen, B., and Ş. Gümüşçü. 2017a. Turkey: How the coup failed. Journal of Democracy 28, no. 1: 59-73. doi:10.1353/jod.2017.0006

Esen, B., and Ş. Gümüşçü. 2017b. A small yes for presidentialism: The Turkish constitutional referendum of April 2017. South European Society and Politics 22, no. 3: 303-26. doi:10.1080/ 13608746.2017.1384341

Esen, B., and Ş. Gümüşçü. 2018. Building a competitive authoritarian regime: State-business relations in the AKP's Turkey. Journal of Balkan and near Eastern Studies 20, no. 4: 349-72. doi:10.1080/19448953.2018.1385924

George, A., and A. Bennett. 2005. Case studies and theory development in the social sciences. Cambridge, MA: MIT Press.

Grigoriadis, I.N. 2009. Islam and democratization in Turkey: Secularism and trust in a divided society. Democratization 16, no. 6: 1194-213. doi:10.1080/13510340903271803

Gümüşçü, S. 2013. The emerging predominant party system in Turkey. Government and Opposition 48, no. 2: 223-44. doi:10.1017/gov.2012.13

Gürsoy, Y. 2011. The impact of EU-driven reforms on the political autonomy of the Turkish military. South European Society and Politics 16, no. 2: 293-308. doi:10.1080/ 13608746.2011.577950

Gürsoy, Y. 2012. The final curtain for the Turkish armed forces? Civil-military relations in view of the 2011 general elections. Turkish Studies 13, no. 2: 191-211. doi:10.1080/14683849.2012.685254 
Jenkins, G. 2008. Political Islam in Turkey: Running West, heading East? New York: Palgrave MacMillan.

Kalaycioğlu, E. 2012. Kulturkampf in Turkey: The constitutional referendum of 12 September 2010. South European Society and Politics 17, no. 1: 1-22. doi:10.1080/13608746.2011.600555

Keyman, E.F., and S. Gümüşçü. 2014. Democracy, identity, and foreign policy in Turkey. Basingstoke: Palgrave Macmillan.

Konak, N., and R. Özgür Dönmez. 2015. Deconstructing a neopatrimonial via humour: Gezi Park 'Capulcu' protests in Turkey'. In Waves of social movement mobilizations in the twentyfirst century, ed. N. Konak and R.Ö. Dönmez, 59-82. Plymouth: Lexington Books.

Kuru, A.T. 2012. The rise and fall of military tutelage in Turkey: Fears of Islamism, Kurdism, and Communism. Insight Turkey 14, no. 2: 37-57.

Levitsky, S., and J. Loxton. 2013. Populism and competitive authoritarianism in the Andes. Democratization 20, no. 1: 107-36. doi:10.1080/13510347.2013.738864

Levitsky, S., and L. Way. 2010. Competitive authoritarianism: Hybrid regimes after the cold war. Cambridge: Cambridge University Press.

Mardin, Ş. 1973. Centre-periphery relations: A key to Turkish politics?. Daedalus 2, no. 1: 169-90. Müftüler-Baç, M. 2016. The Pandora's box: Democratization and rule of law in Turkey. AsiaEurope Journal 14, no. 1: 61-77. doi:10.1007/s10308-015-0435-9

Müftüler-Baç, M., and E.F. Keyman. 2012. The era of dominant-party politics. Journal of Democracy 23, no. 1: 85-99. doi:10.1353/jod.2012.0000

Öktem, K., and K. Akkoyunlu. 2016. Exit from democracy: Illiberal governance in Turkey and beyond. Southeast European and Black Sea Studies 16, no. 4: 469-80. doi:10.1080/14683857.2016.1253231

Öniş, Z. 2013. Sharing power: Turkey's democratization challenge in the age of the AKP hegemony. Insight Turkey 15, no. 2: 103-22.

OSCE/ODIHR. 2015. Election assessment mission report, Republic of Turkey, parliamentary elections, November 1. www.osce.org/odihr/elections/turkey/186031.

OSCE/ODIHR. 2017. Republic of Turkey. constitutional referendum, limited referendum observation mission final report. April 16. http://www.osce.org/odihr/elections/turkey/324816? download=true.

Özbudun, E. 2006. From political Islam to conservative democracy: The case of the justice and development party in Turkey. South European Society and Politics 11, no. 3-4: 543-57. doi:10.1080/13608740600856561

Özbudun, E. 2014. AKP at the crossroads: Erdoğan's majoritarian drift. South European Society and Politics 19, no. 2: 155-67. doi:10.1080/13608746.2014.920571

Özbudun, E. 2015. Turkey's judiciary and the drift toward competitive authoritarianism. The International Spectator 50, no. 2: 42-55. doi:10.1080/03932729.2015.1020651

Schenkkan, N. 2017. One year after the coup attempt, Turkey is more fragile than ever. Freedom House, July 13. https://freedomhouse.org/blog/one-year-after-coup-attempt-turkey-morefragile-ever.

Selçuk, O. 2016. Strong presidents and weak institutions: Populism in Turkey, Venezuela and Ecuador. Southeast European and Black Sea Studies 16, no. 4: 571-89. doi:10.1080/ 14683857.2016.1242893

Somer, M. 2016. Understanding Turkey's democratic breakdown: Old vs. new and indigenous vs. global authoritarianism. Southeast European and Black Sea Studies 16, no. 4: 481-503. doi:10.1080/14683857.2016.1246548

Taş, H. 2015. Turkey - From tutelary to delegative democracy. Third World Quarterly 36, no. 4: 776-91. doi:10.1080/01436597.2015.1024450

Tocci, N. 2005. Europeanization in Turkey: Trigger or anchor for reform? South European Society and Politics 10, no. 1: 73-83. doi:10.1080/13608740500037973

Tuğal, C. 2009. Passive revolution: absorbing the Islamic challenge to capitalism. Stanford: Stanford University Press.

Türkmen-Dervişoğlu, G. 2015. Turkey: From 'role model' to 'illiberal democracy'. Open Democracy, December 11. www.opendemocracy.net/can-europe-make-it/gulay-turkmendervisoglu/turkey-from-role-model-to-illiberal-democracy 
White, D., and M. Herzog. 2016. Examining state capacity in the context of electoral authoritarianism, regime formation and consolidation in Russia and Turkey. Southeast European and Black Sea Studies 16, no. 4: 551-69. doi:10.1080/14683857.2016.1242891

Yabanci, B. 2016. Populism as the problem child of democracy: The AKP's enduring appeal and 870 the use of meso-level actors. Southeast European and Black Sea Studies 16, no. 4: 591-617. doi:10.1080/14683857.2016.1242204

Yabanci, B., and D. Taleski. 2018. Co-opting religion: How ruling populists in Turkey and Macedonia sacralise the majority. Religion, State \& Society 46, no. 3: 283-304. doi:10.1080/ 09637494.2017.1411088

Yildiz, U.B. 2014. Rethinking civil-military relations in Turkey: The problems of the democratic governance of the defense and security sectors. Turkish Studies 15, no. 3: 386-401. doi:10.1080/14683849.2014.954744

Yllmaz, G. 2016. Europeanisation or de-Europeanisation? Media freedom in Turkey (1999-2015). South European Society and Politics 21, no. 1: 147-61. doi:10.1080/13608746.2016.1148102 